OECD Working Papers on Finance, Insurance and Private Pensions No. 4

\title{
The EU Stress Test and Sovereign Debt Exposures
}

\section{Adrian Blundell-Wignall,} Patrick Slovik 


\section{OECD WORKING PAPERS ON FINANCE, INSURANCE AND PRIVATE PENSIONS}

The Finance, Insurance and Private Pensions working paper series contains selected studies on finance, insurance and private pensions policy prepared for dissemination within the OECD and interested audiences to stimulate discussion and further analysis in the areas covered. The studies provide timely analysis of and background information on structural issues, developments and policies in the area of financial markets, insurance and private pensions, including financial education.

The papers are generally available only in their original language - English or French - with a summary in the other if available.

The opinions expressed in these papers are the sole responsibility of the author(s) and do not necessarily reflect those of the OECD or the governments of its member countries.

Comment on the series is welcome, and should be sent to either daf.contact@oecd.org or the Financial Affairs Division, OECD, 2, rue André Pascal, 75775 PARIS CEDEX 16, France.

OECD Working Papers on Finance, Insurance and Private Pensions are published on www.oecd.org/daf/fin/wp

(C) OECD 2010

Applications for permission to reproduce or translate all or part of this material should be made to: OECD Publishing, rights@oecd.org or by fax 33145249930. 


\section{Abstract \\ THE EU STRESS TEST AND SOVEREIGN DEBT EXPOSURES}

by

Adrian Blundell-Wignall and Patrick Slovik ${ }^{*}$

This working paper's quantifications show that most sovereign debt is held on the banking books of banks, whereas the EU stress test considered only their small trading book exposures. It discusses why sovereign debt held in the banking book cannot be ignored by investors and creditors, because of: (a) recovery values in the event of individual bank failures; and (b) fiscal sustainability and structural competitiveness issues which mean the market cannot give a zero probability to debt restructurings beyond the period of the stress test and/or the period after which the role of the European Financial Stability Facility Special Purpose Vehicle (EFSF SPV) comes to an end. How the SPV could operate to shift sovereign risk from banks to the public sector is also an important part of the discussion.

JEL classification: G21, G28, E62

Keywords: EU stress test, sovereign debt, financial stability, banking system

\footnotetext{
* Adrian Blundell-Wignall is Special Adviser to the OECD Secretary General on Financial Markets and Deputy Director of the Financial \& Enterprise Affairs Directorate. Patrick Slovik is an economist at the OECD. The views expressed in these working notes are entirely those of the authors and do not reflect any opinion of the OECD or its member governments. Comments are welcome.
} 


\title{
TABLE OF CONTENTS
}

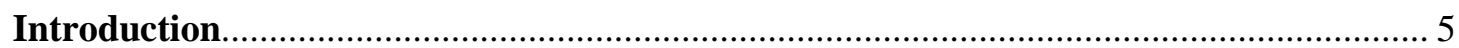

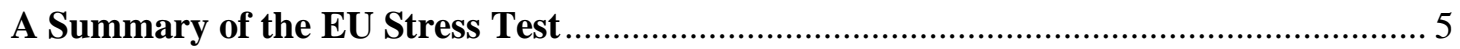

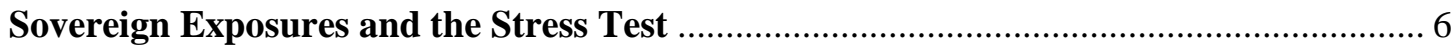

The Assumption of No Bank Failures and no Sovereign Defaults .................................... 9

No bank failures: accounting versus economic interest ..................................................... 9

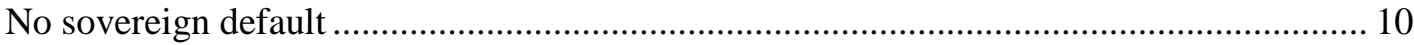

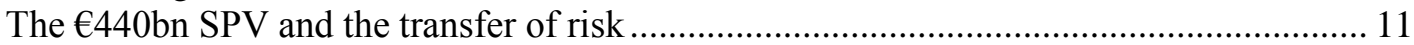

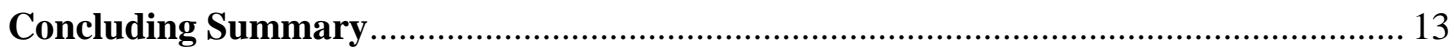

\section{Boxes}

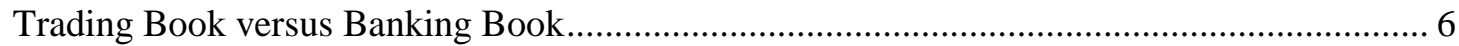

\section{Figures}

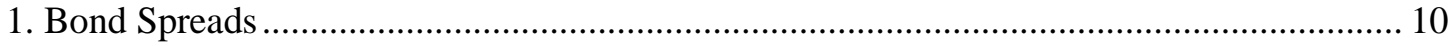

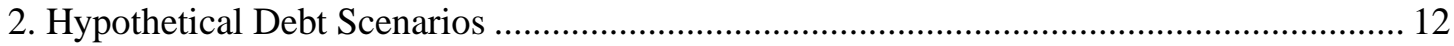

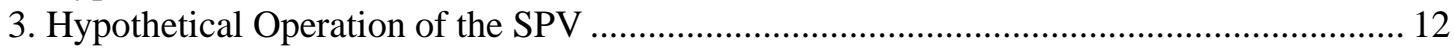

\section{Tables}

1. Trading Versus Banking Book Sovereign Debt Exposures of EU Banks ............................ 7

2. Country Banking Exposure to Sovereign Debt of Greece, Portugal, Spain, Ireland, Italy and Hungary ....

\author{
8
}

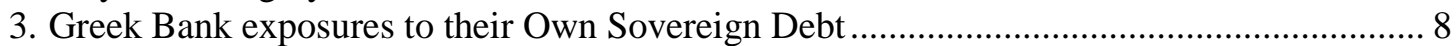

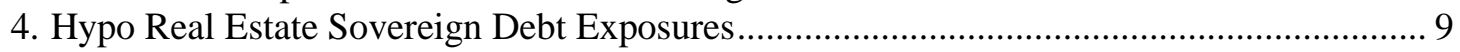

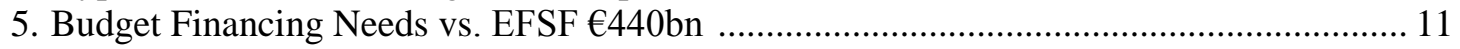




\section{Introduction}

In the past month EU policy makers have completed and published their stress test for the EU banking system ${ }^{1}$. The results showed a very resilient banking system with strong capital positions in the benchmark case and a sound performance in an adverse risk scenario including the sovereign crisis. Notwithstanding these results, markets have continued to be concerned about sovereign risk issues, and continue to price default in some countries. Equity markets have also performed poorly and banks remain reluctant to lend.

Other policy developments appear more concerned with banking risk within Europe. Prior to the stress test a vast European Financial Stability Facility (EFSF) was set up, including importantly a special purpose vehicle (SPV) with the ability to raise $€ 440 \mathrm{bn}$ in euro area guaranteed bonds to lend to governments facing financing difficulties. At he same time, there has been considerable pullback from the Basel III proposals of December 2009.

This note summarises the stress test and appraises the way it has treated the sovereign debt crisis using new data on bank exposures to sovereign debt. It uses these findings to comment on market concerns about banking sector exposure to sovereign debt during and beyond the period of the stress test.

\section{A Summary of the EU Stress Test}

The main features of the stress test are as follows:

- It relates to 91 banks in EU member countries for 2010 and 2011 only.

- A global macro confidence shock is compared to a benchmark economic scenario for the EU in 2010 and 2011. This shock causes a modest double dip recession.

- There is an upward shift in the yield curve and a widening of spreads related to the EU sovereign debt crisis, applied for the average 5-year duration bond rates. This shock of 145 basis points (bp) consists of 2 components: a 75bp upward move in the yield curve common to all EU countries due to the sovereign crisis; and an additional effect for individual countries (e.g. 685bp for Greece, 268bp for Portugal, 158bp for Ireland and 142bp for Spain, $86 \mathrm{bp}$ for Italy) that aggregate to a further $70 \mathrm{bp}$.

- Probability of Default (PD) and Loss Given Default (LGD) were calculated for 5 portfolios (financial institutions, sovereign, corporate, consumer credit/retail, and retail real estate) using regression model elasticities linked to the macro variables, national supervisory inputs, the ECB Monetary and Financial Institutions database, and the LGD database at Moody's.

- Sovereign bond haircuts were applied to the trading book holdings only, as there is an assumption that in the banking book there can be no sovereign defaults-so bonds held to maturity will receive 100 cents in the euro. The haircuts use the discounted cash flow model and Bloomberg data.

- All government support packages are assumed to stay in place beyond the time horizon of the exercise and a zero growth assumption is used for bank credit and market risk exposures.

\footnotetext{
${ }^{1}$ See Committee of European Banking Supervisors (CEBS), Aggregate Outcome of the 2010 EU Wide Stress Test Exercise-Coordinated by CEBS in Cooperation with the ECB. 23 July 2010.
} 
The results of this exercise appear quite encouraging. Tier 1 capital rises strongly in the benchmark due to very solid earnings growth (e.g. with a steep yield curve) and there are declining impairment charges. In the worse case adverse scenario banks suffer impairment and trading losses including sovereign haircuts amounting to $€ 565 \mathrm{bn}$ over the 2 years, but fortuitously earnings over that same period amount to $€ 509 \mathrm{bn}$, so the net impact on capital (assuming no dividends) is a mere $€ 59 \mathrm{bn}$. The aggregate Tier 1 ratio falls only from $10.3 \%$ for the 91 banks to $9.2 \%$ in the adverse scenario, and mainly because the risk-weighted assets rise (the 4 notch credit quality decline in securitisation ratings causes risk weightings of the asset to increase).

At the individual bank level only 7 banks see their Tier 1 capital ratio move below a level of $6 \%$ set for the exercise in the adverse case. Banks appear to be resoundingly resilient in Europe. If the macro scenario is closer to the benchmark central case, then the aggregate Tier 1 capital ratio would rise to $11.2 \%$ - a very happy state indeed.

\section{Sovereign Exposures and the Stress Test}

The EU-wide stress test did not include haircuts for sovereign debt held in the banking books of banks on the grounds that over the 2 years considered default is virtually impossible in the presence of the EFSF, which is certainly large enough to meet funding needs of the main countries of concern (see below) over that period.

\section{Box: Trading Book versus Banking Book}

To understand the EU stress test it is important to distinguish the trading book from the banking book of a bank. The trading book of a bank consists of financial assets held at fair value through profit or loss and are marked to market: bank own positioning in financial instruments for profit; the execution of trade orders from customers; market making; and positions taken to hedge other elements of the trading book. All (often longerterm) exposures that aren't in the trading book are referred to as the banking book. The latter is usually divided between exposures to: sovereign debt; retail instruments (mortgages, consumer revolving, etc); equity; and 'other' (mainly corporate) exposures.

This 'other' corporate component consists of loans to small and medium-sized businesses (SMEs), but also includes lending usually associated with special purpose entities (SPEs). SPEs typically raise liabilities and choose the assets, while the revenue from the assets is used to service the liabilities (e.g. project/infrastructure finance, object finance like aircraft leasing, commodity financing, income producing real estate and other pooled structured products).

Exposures held in the banking book are in principle held to maturity, and may be carried at values which differ from what their mark-to-market value (affected by liquidity) might be in the trading book. In the case of sovereign debt, provided there are no defaults or restructurings, this would be at 100 cents in the euro. In the case of non-sovereign assets, banks will choose to carry them in the banking book, and even reclassify assets from the trading to the banking book, if they believe the value if held to maturity exceeds their mark-to-market value in the trading book.

The haircuts applied to the trading book in the stress test are shown in the first block of Table 1. The trading book exposures (not reported in the stress test paper) are also shown. The EU wide loss from the haircut is around $€ 26.4 \mathrm{bn}$. The contribution of the 5 countries where most of the market focus has been (Greece, Portugal, Ireland, Italy and Spain) is only $€ 14.4 \mathrm{bn}$.

A different picture emerges when we consider the banking book. First it is important to note that the EU banking book sovereign exposures are very much larger than those of the trading bookaround $83 \%$ of the total. If the same haircuts are applied to these exposures the loss amounts 
to $€ 139 \mathrm{bn}$, or $12 \%$ of the Tier 1 capital of the EU banks at the end of 2009 (and $€ 165 \mathrm{bn}$ and over $14 \%$ of Tier 1 if trading book losses are added in). The haircuts of the 5 countries of market focus amount to $€ 75.8 \mathrm{bn}$ in the banking book, and $€ 90.2 \mathrm{bn}$ if the trading book amount is added in. This is around $8 \%$ of EU Tier 1 capital of stress tested banks.

Table 1: Trading Versus Banking Book Sovereign Debt Exposures of EU Banks

\begin{tabular}{|c|c|c|c|c|c|c|}
\hline & \multicolumn{3}{|c|}{ Trading Book } & \multicolumn{3}{|c|}{ Banking Book } \\
\hline & Exposures & Haircut $\%$ & Haircut Value & Exposures & Haircut $\%$ & Haircut Value \\
\hline & Euro million & $\%$ & Euro million & Euro million & $\%$ & Euro million \\
\hline Austria & 4,418 & $5.6 \%$ & 247 & 39,052 & $5.6 \%$ & 2,187 \\
\hline Belgium & 9,115 & $6.9 \%$ & 629 & 74,650 & $6.9 \%$ & 5,151 \\
\hline Cyprus & 87 & $6.7 \%$ & 6 & 1,909 & $6.7 \%$ & 128 \\
\hline Finland & 4,804 & $6.1 \%$ & 293 & 9,113 & $6.1 \%$ & 556 \\
\hline France & 43,493 & $6.0 \%$ & 2,610 & 146,651 & $6.0 \%$ & 8,799 \\
\hline Germany & 63,194 & $4.7 \%$ & 2,970 & 421,454 & $4.7 \%$ & 19,808 \\
\hline Greece & 13,038 & $23.1 \%$ & 3,012 & 96,284 & $23.1 \%$ & 22,242 \\
\hline Ireland & 4,476 & $12.8 \%$ & 573 & 25,476 & $12.8 \%$ & 3,261 \\
\hline Italy & 96,705 & $7.4 \%$ & 7,156 & 228,040 & $7.4 \%$ & 16,875 \\
\hline Luxembourg & 2,999 & $6.9 \%$ & 207 & 5,596 & $6.9 \%$ & 386 \\
\hline Malta & 17 & $6.4 \%$ & 1 & 1,479 & $6.4 \%$ & 95 \\
\hline \begin{tabular}{|l} 
Netherlands \\
\end{tabular} & 10,612 & $5.2 \%$ & 552 & 63,840 & $5.2 \%$ & 3,320 \\
\hline Portugal & 7,825 & $14.1 \%$ & 1,103 & 37,433 & $14.1 \%$ & 5,278 \\
\hline Slovakia & 2,740 & $5.0 \%$ & 137 & 11,812 & $5.0 \%$ & 591 \\
\hline Slovenia & 1,032 & $4.2 \%$ & 43 & 3,432 & $4.2 \%$ & 144 \\
\hline Spain & 21,597 & $12.0 \%$ & 2,592 & 234,257 & $12.0 \%$ & 28,111 \\
\hline Euro-Area & 286,150 & $7.7 \%$ & 22,131 & $1,400,477$ & $8.3 \%$ & 116,930 \\
\hline Non-Euro Area & 49,468 & $8.7 \%$ & 4,296 & 205,537 & $10.6 \%$ & 21,744 \\
\hline European Union & 335,619 & $7.9 \%$ & 26,426 & $1,606,014$ & $8.6 \%$ & 138,675 \\
\hline
\end{tabular}

It is also important to note that the exposures are not evenly distributed — with the banks in some countries more heavily exposed to the countries of focus in the sovereign debt crisis than others. Table 2 shows the exposures of the banks in the country shown to the sovereign debt of Greece, Portugal, Ireland, Spain, Italy and Hungary: both gross exposures and the percentage of Tier 1 capital they represent are shown (the impact of on bank capital can be obtained by applying a haircut assumption to the latter).

The main observations are:

- Banks tend to be heavily exposed to the sovereign debt of their own country. The exposure of Greek banks to Greek sovereign debt represents $226 \%$ of their Tier 1 capital. In Italy, Hungary, Spain, Portugal, and Ireland these numbers are 157\%, 133\%, 113\%, 69\% and 26\%, respectively.

- Large cross-border exposures (defined as an exposure above 5\% of Tier 1 capital) to Greece are present for Germany, France, Belgium (all with systemically important banks), Cyprus and Portugal. Large exposures to Portugal are present in Germany and Belgium; to Spain in Germany and Belgium; to Italy in Germany, France, Netherlands, Belgium, Luxembourg, Austria and Portugal; and to Ireland in Germany and Cyprus.

- Some banking systems are also exposed to non-euro area sovereign debt not subject to the EFSF: for example, Austrian, Belgian and German exposures to Hungary are above the notional 5\% threshold. 
Nor is the distribution of exposure even between individual banks within a country. Table 3 shows the exposures of Greek banks to their own-country sovereign debt - any haircut would be problematic on current holdings.

Table 4 shows the example in Germany of Hypo Real Estate (already once saved by the German government). Virtually all of the exposures are in the banking book and therefore were excluded from the stress test. But the potential impact of any restructuring of debt, were it to occur in a future scenario beyond the period of the stress test, would be problematic for any individual bank with such large exposures.

\section{Table 2: Country Banking Exposure to Sovereign Debt of Greece, Portugal, Spain, Ireland, Italy and Hungary}

\begin{tabular}{|l|r|r|}
\hline EUR millions & Exposures to Greece & Exposure / Tier 1 Capital \\
\hline Greece & 56,148 & $226 \%$ \\
\hline Germany & 18,718 & $12 \%$ \\
\hline France & 11,624 & $6 \%$ \\
\hline Cyprus & 4,837 & $109 \%$ \\
\hline Belgium & 4,656 & $14 \%$ \\
\hline United Kingdom & 4,131 & $1 \%$ \\
\hline Netherlands & 3,160 & $4 \%$ \\
\hline Italy & 1,778 & $2 \%$ \\
\hline Portugal & 1,739 & $9 \%$ \\
\hline Spain & 1,016 & $1 \%$ \\
\hline
\end{tabular}

\begin{tabular}{|l|r|r|}
\hline EUR millions & Exposures to Portugal & Exposure / Tier 1 Capital \\
\hline Portugal & 13,707 & $69 \%$ \\
\hline Germany & 10,888 & $7 \%$ \\
\hline Spain & 6,807 & $4 \%$ \\
\hline France & 4,864 & $3 \%$ \\
\hline Belgium & 2,982 & $9 \%$ \\
\hline United Kingdom & 2,571 & $1 \%$ \\
\hline Netherlands & 2,272 & $3 \%$ \\
\hline Italy & 304 & $0.3 \%$ \\
\hline Austria & 272 & $1 \%$ \\
\hline Ireland & 257 & $1 \%$ \\
\hline
\end{tabular}

\begin{tabular}{|l|r|r|}
\hline EUR millions & Exposures To Spain & Exposure / Tier 1 Capital \\
\hline Spain & 203,310 & $113 \%$ \\
\hline Germany & 31,854 & $21 \%$ \\
\hline France & 6,592 & $4 \%$ \\
\hline United Kingdom & 5,916 & $2 \%$ \\
\hline Belgium & 3,530 & $11 \%$ \\
\hline Netherlands & 1,685 & $2 \%$ \\
\hline Italy & 1,383 & $2 \%$ \\
\hline Ireland & 391 & $2 \%$ \\
\hline Portugal & 345 & $2 \%$ \\
\hline Austria & 239 & $1 \%$ \\
\hline
\end{tabular}

\begin{tabular}{|l|r|r|}
\hline EUR millions & Exposures To Ireland & Exposure / Tier 1 Capital \\
\hline Germany & 12,922 & $8 \%$ \\
\hline United Kingdom & 5,580 & $2 \%$ \\
\hline Ireland & 5,322 & $26 \%$ \\
\hline France & 2,476 & $1 \%$ \\
\hline Portugal & 839 & $4 \%$ \\
\hline Denmark & 675 & $4 \%$ \\
\hline Belgium & 593 & $2 \%$ \\
\hline Netherlands & 559 & $1 \%$ \\
\hline Cyprus & 440 & $10 \%$ \\
\hline Italy & 239 & $0.3 \%$ \\
\hline
\end{tabular}

\begin{tabular}{|l|r|r|}
\hline EUR millions & Exposures To Italy & Exposure / Tier 1 Capital \\
\hline Italy & 144,856 & $157 \%$ \\
\hline Germany & 72,717 & $48 \%$ \\
\hline France & 48,185 & $26 \%$ \\
\hline Belgium & 25,194 & $76 \%$ \\
\hline Netherlands & 10,313 & $14 \%$ \\
\hline United Kingdom & 10,029 & $4 \%$ \\
\hline Spain & 6,017 & $3 \%$ \\
\hline Luxembourg & 2,505 & $158 \%$ \\
\hline Austria & 1,474 & $7 \%$ \\
\hline Portugal & 1,179 & $6 \%$ \\
\hline
\end{tabular}

\begin{tabular}{|l|r|r|}
\hline EUR millions & Exposures to Hungary & Exposure / Tier 1 Capital \\
\hline Germany & 8,215 & $5 \%$ \\
\hline Hungary & 4,931 & $133 \%$ \\
\hline Austria & 4,335 & $21 \%$ \\
\hline Italy & 2,253 & $2 \%$ \\
\hline Belgium & 2,189 & $7 \%$ \\
\hline France & 1,881 & $1 \%$ \\
\hline United Kingdom & 452 & $0.2 \%$ \\
\hline Spain & 251 & $0.1 \%$ \\
\hline Netherlands & 188 & $0.2 \%$ \\
\hline Greece & 80 & $0.3 \%$ \\
\hline
\end{tabular}

Table 3: Greek Bank Exposures to their Own Sovereign Debt

National Bank of Greece Agricultural Bank of Greece Piraeus Bank Group Eurobank EGF TT Hellenic Postbank Alpha Bank

Greek Banks Source: OECD, bank reports.

\section{Exposures to Greek Sovereign Debt}

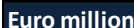

o/w Banking Book (\%)

o/w Trading book (\%)

\begin{tabular}{|r|r|r|}
\hline $\mathbf{1 9 , 7 5 6}$ & $91.8 \%$ & $8.2 \%$ \\
\hline $\mathbf{1 0 , 1 8 7}$ & $93.5 \%$ & $6.5 \%$ \\
\hline $\mathbf{8 , 3 0 6}$ & $87.1 \%$ & $12.9 \%$ \\
\hline $\mathbf{7 , 4 5 8}$ & $98.7 \%$ & $1.3 \%$ \\
\hline $\mathbf{5 , 3 7 1}$ & $97.2 \%$ & $2.8 \%$ \\
\hline $\mathbf{5 , 0 7 0}$ & $96.9 \%$ & $3.1 \%$ \\
\hline $\mathbf{5 6 , 1 4 8}$ & $93.3 \%$ & $6.7 \%$ \\
\hline
\end{tabular}

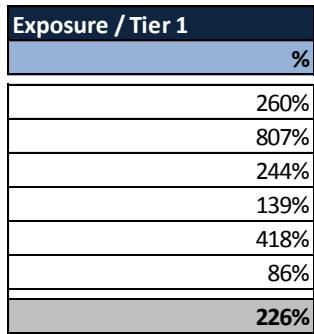


Table 4: Hypo Real Estate Sovereign Debt Exposures

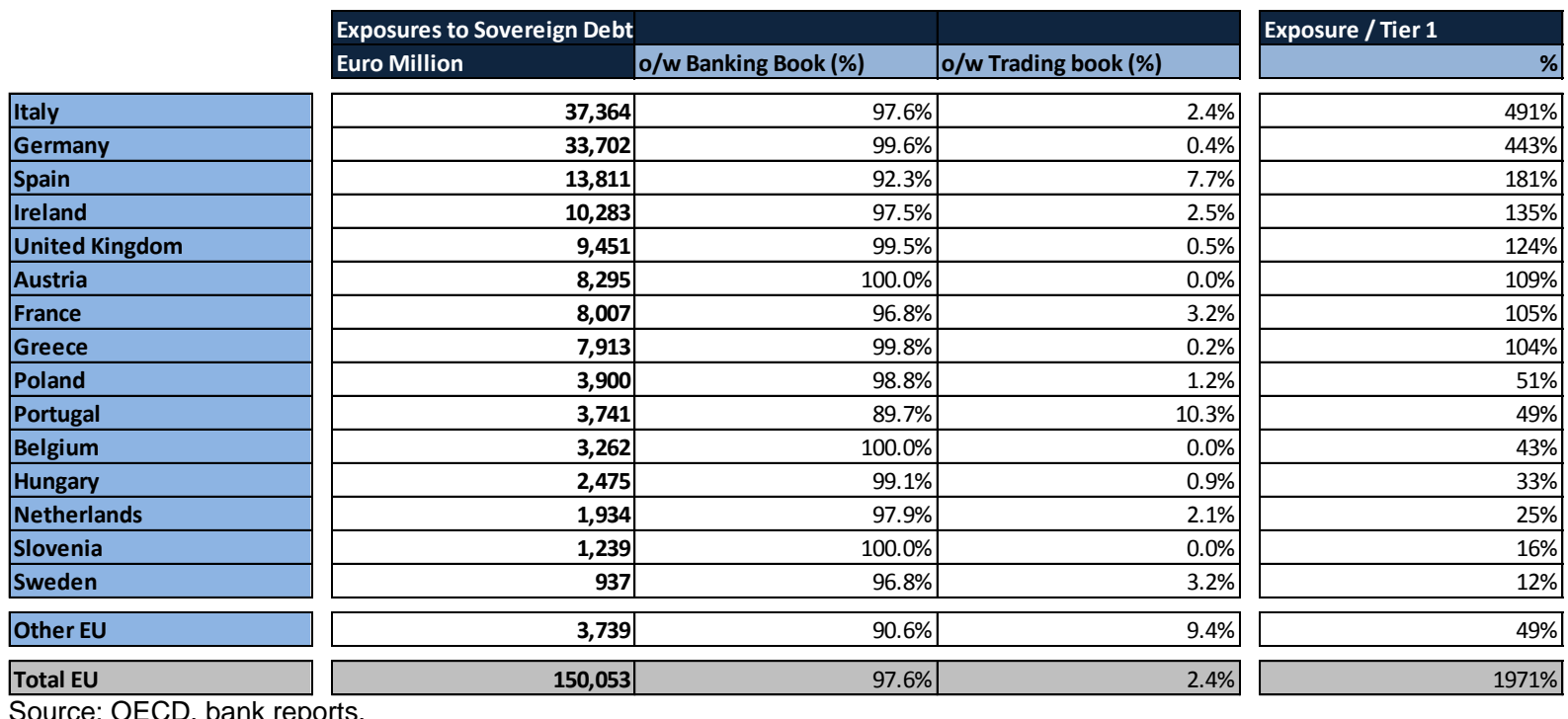

\section{The Assumption of No Bank Failures and no Sovereign Defaults}

The above data raise a number of issues worth discussing in the context of the stress test and market concerns. Equity markets continue to perform poorly, bond spreads remain elevated (see Figure 1), and banks remain reluctant to lend. The encouraging stress test results seem on the face of it to be at odds with these developments. This difference is due in part to the assumptions of no bank failures and no sovereign default implicit in the stress test.

\section{No bank failures: accounting versus economic interest}

If a bank fails, the questions of whether sovereign exposures are in the banking book or in the trading book disappear. If a bank were to fail, the resolution authority would have to realize asset sales in the market to meet demands from depositors and other creditors. The latent losses on the sovereign portfolio in the banking book would be realized. Therefore, shifts in the market values of sovereign debt held on banking books must be relevant for creditors and stakeholders, unless stress-tested banks can be assumed never to fail. Similar comments would apply to other assets, including SPE structured products that may currently be worth more in the banking book than in the trading book. Banks have been choosing to hold assets in the banking book and in many cases to reclassify assets to take advantage of better valuations. Shareholders and/or creditors have to make their own assessments about the probability of solvency events in individual banks which could affect their recovery of funds in the event of insolvencies. 
Figure 1: Bond Spreads

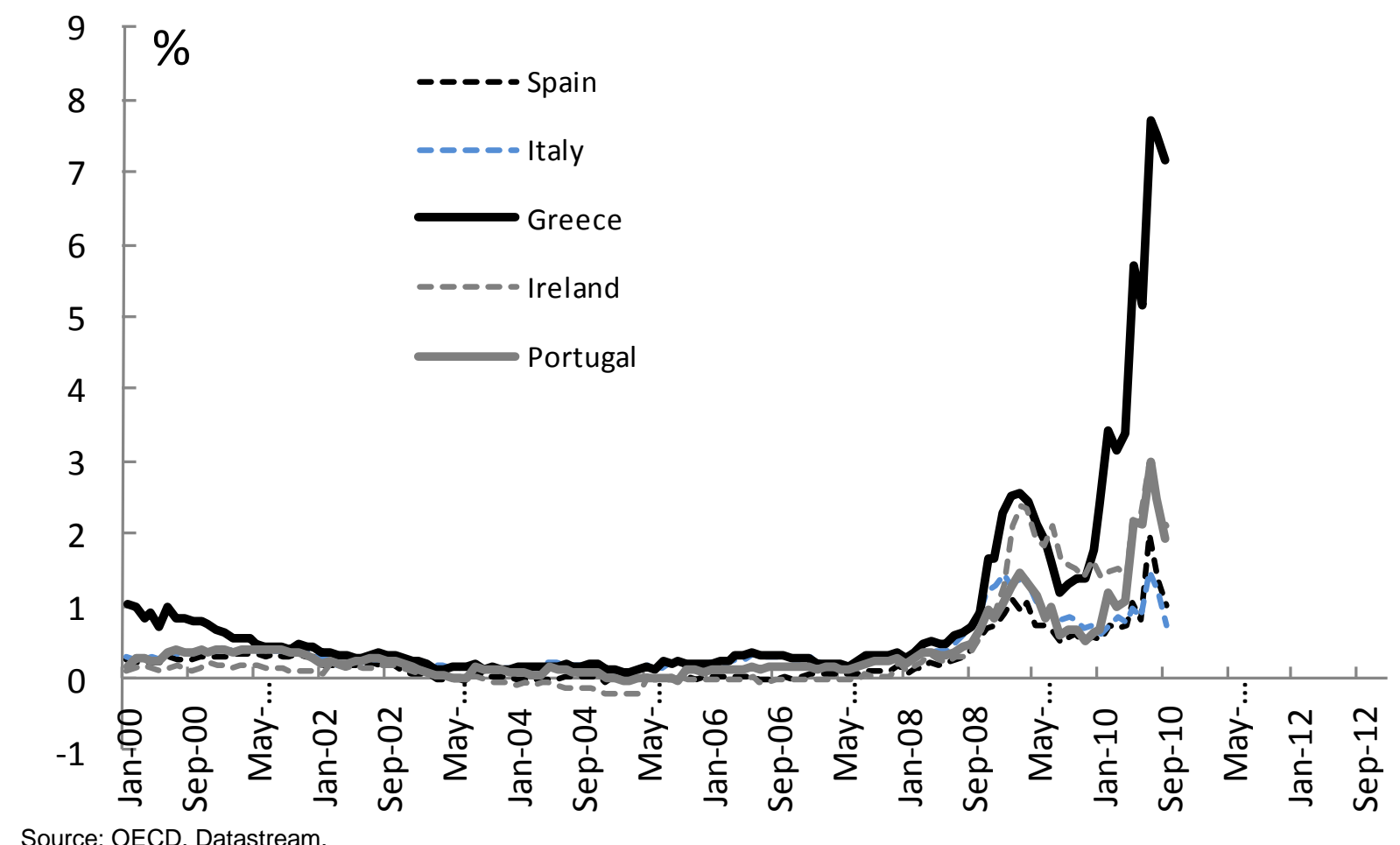

\section{No sovereign default}

The assumption of no sovereign default over the period of 2010 and 2011 appears to be very reasonable. The EFSF is made up of a $€ 720 \mathrm{bn}$ lending facility ( $€ 220 \mathrm{bn}$ from the IMF; $€ 60 \mathrm{bn}$ from the $\mathrm{EU}$; and the SPV can build exposures for 3 years to the limit of $€ 440 \mathrm{bn}$ for the 16 Euro area countries) which provides a guarantee of funding for any countries facing financing pressures, certainly for the next 3 years.

Table 5 shows the approximate funding needs of Italy, Spain, Greece, Ireland and Portugal based on simulations using OECD growth and deficit forecasts. The EFSF could more than cover all of the funding needs of these countries, even in the unlikely case that no securities could be sold on the open market, for the period of the stress test (2009-2011). So the assumption of no default over this short period is reasonable.

The concerns in the market beyond 2012 are: the longer-run fiscal sustainability problem; and the difficulty of achieving structural adjustments in labour and pension markets needed to ensure sustainable growth in a period of budget restraint. The fear is that this will not be resolved by the time the support packages run out, and hence the probability of restructuring may not be put at zero by portfolio managers. 
Table 5: Budget Financing Needs vs. EFSF $€ 440 \mathrm{bn}$ (€720bn including funding from the IMF \& EU)

\begin{tabular}{|c|c|c|c|}
\hline & \multicolumn{3}{|c|}{ Budget Financing Needs (Euro billion) } \\
\hline & $2009-2011$ & $2009-2012$ & 2009-2013 \\
\hline Spain & 173 & 253 & 333 \\
\hline Greece & 38 & 57 & 81 \\
\hline Ireland & 33 & 51 & 70 \\
\hline Portugal & 25 & 37 & 53 \\
\hline Italy & 185 & 273 & 367 \\
\hline TOTAL excluding Italy & 269 & 398 & 537 \\
\hline TOTAL including Italy & 454 & 671 & 904 \\
\hline
\end{tabular}

Figure 2 shows sovereign debt level projections as a share of GDP for Spain, Greece, Ireland and Portugal. ${ }^{2}$ The solid line in each case shows a hypothetical benchmark based on the assumption of on no budget measure to cut deficits. In all cases debt rises unsustainably. The dashed line shows a purely hypothetical alternative of budget policies that would be needed to return debt levels to the 2009 starting point as a share of GDP. The fiscal adjustment assumptions imposed in this exercise are: (a) that budget cuts must be bigger in the early years, but (b) the cyclically-adjusted primary deficit can't be cut by more than 3\% of GDP in any one year. The figures in parentheses show the number of years and the total amount the primary deficits would have to be cut in order to meet the debt level objective. The required fiscal adjustments extend beyond the years to which the stress test and support packages apply.

\section{The E440bn SPV and the transfer of risk}

Figure 3 shows a simple stylised picture of how the SPV could work to help meet government financing needs, while also reducing the sovereign bond exposures in the banking sector. If a bank with a hypothetical balance sheet of $€ 100$ holds a $€ 10$ sovereign bond of a fiscally-exposed country, and its duration is less than the 3 years life of the SPV, then it can simply let the debt roll off its banking book without re-financing it. The funding gap for the government concerned would be met by a direct $€ 10$ loan from the SPV, which would raise $€ 10$ of European-wide guaranteed SPV bonds. The bank could bid for these SPV bonds - thereby essentially exchanging sovereign debt for higher quality (though lower returning) SPV assets. Alternatively, the bank could de-lever (let its balance sheet fall); or lend (helping the economy). Some other entity would buy the SPV bonds (e.g. sovereign wealth funds, pension funds etc). Regardless, in this example, sovereign risk is transferred from the bank's balance sheet to the public sector's balance sheet.

\footnotetext{
${ }^{2}$ It needs to be pointed out that the assumption of no policy adjustment is purely a counterfactual exercise to establish a benchmark case. In fact all governments have already begun taking measures.
} 
Figure 2: Hypothetical Debt Scenarios

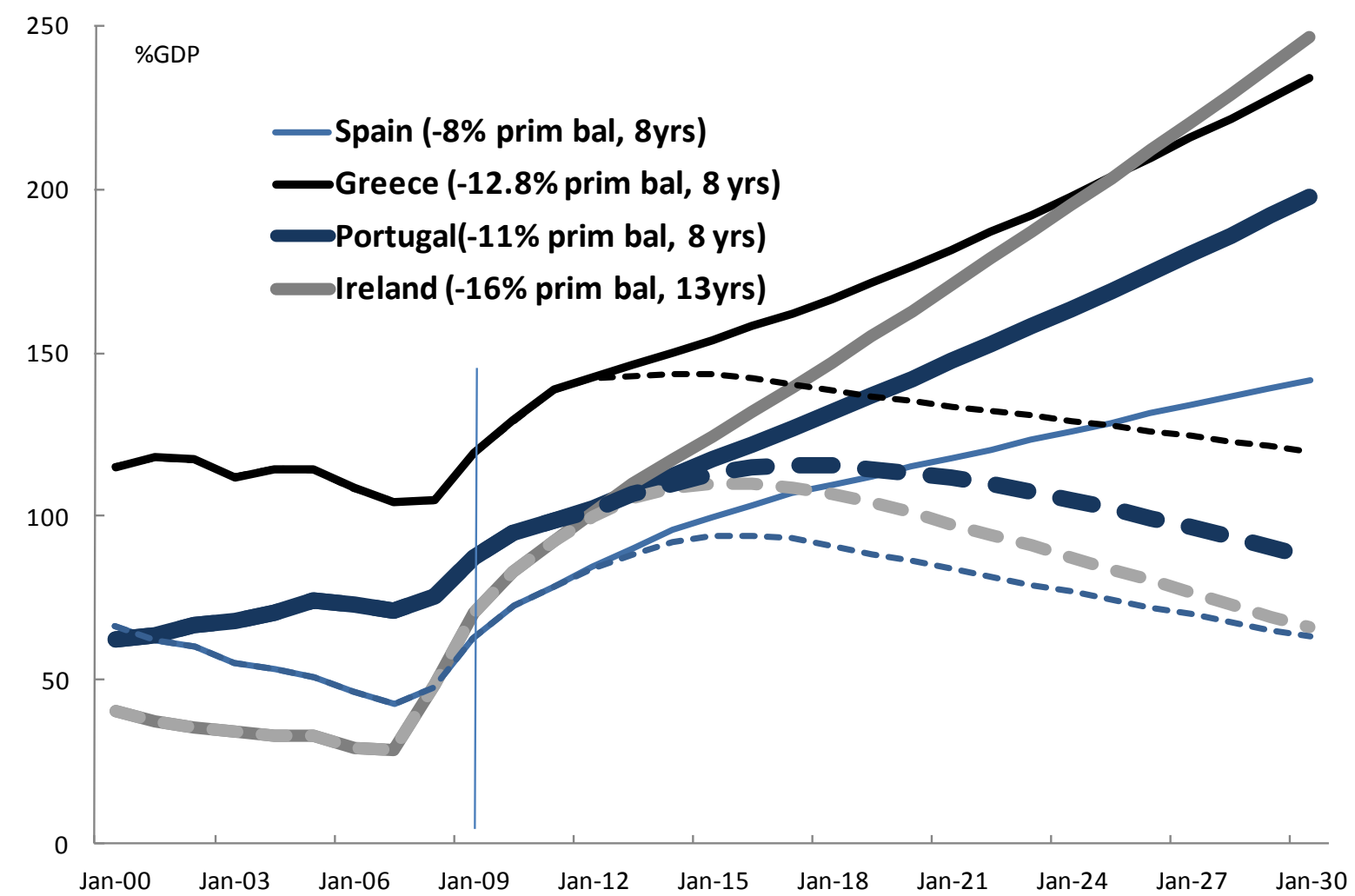

Source: OECD, Datastream.

Figure 3: Hypothetical Operation of the SPV

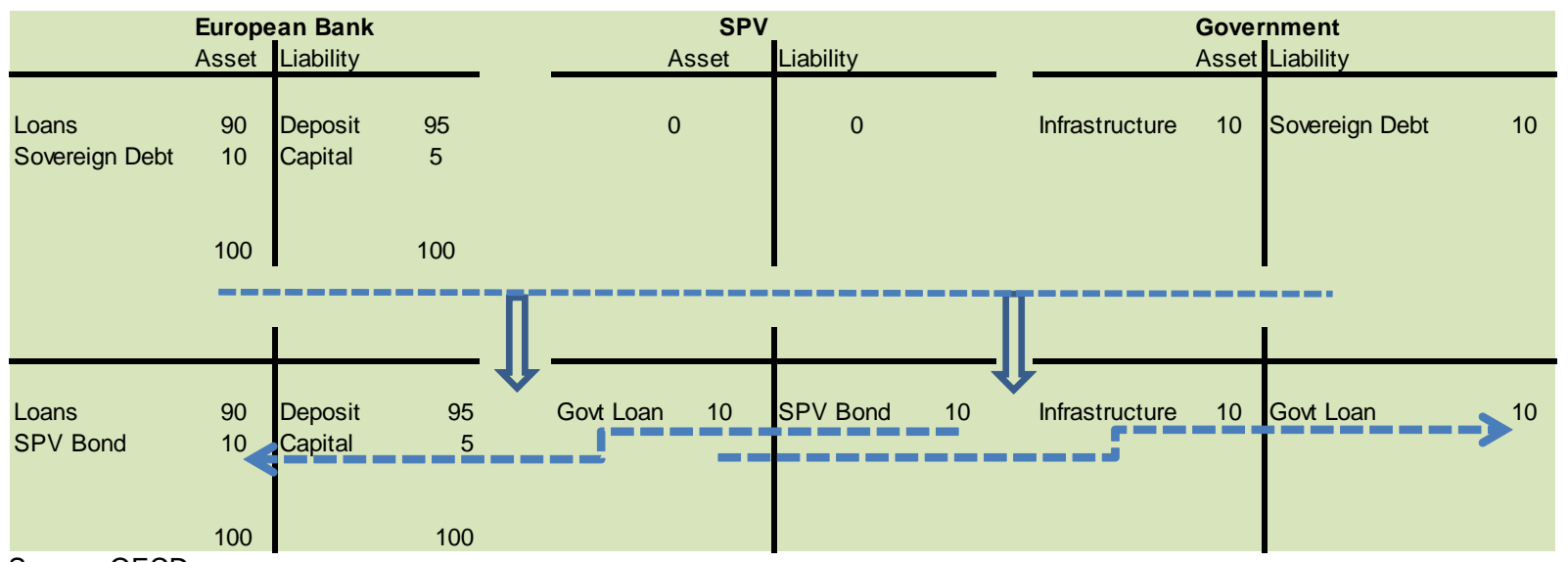




\section{Concluding Summary}

At the Pittsburgh G20 summit it was proposed that the new capital rules-Basel III-be completed and quantified by the end of 2010, after completing the Quantitative Impact Study (QIS). The new reforms were then proposed to be fully implemented by the end of 2012. Since then there have been some considerable changes that weaken the original intent, and the time period for introducing the leverage ratio has been extended out to 2017. At the same time, banks have not been lending and markets continue to perform poorly. The EU stress test on the other hand showed banks in the benchmark case to be very robust to 2011, and even if subjected to a significant adverse macro shock and a sovereign debt haircut, most would come through intact.

This study has shown that most of the sovereign debt is held on the banking books of banks, whereas the EU stress test only considered their small trading book exposures. Sovereign debt held in the banking book cannot be ignored however. First, individual bank failures would see latent losses on the trading book realized, a fact that creditors and equity investors need to take into account. Second, and more importantly, the market is not prepared to give a zero probability to debt restructurings beyond the period of the stress test and/or the period after which the role of the EFSF SPV comes to an end. The main reasons for this are: the very large job ahead for fiscal consolidation in a period of weak economic growth; and the apparent difficulty of achieving structural/competitiveness reforms in some countries in a short period of time. The paper also showed that excessively exposed banks in principle can reduce their exposure by not re-financing maturing sovereign debt, with the government funding gap being met instead by the SPV. This would have the effect of transferring sovereign risk from the bank concerned to the public sector. 